Vol. 7, No. 1, 2021

Alina Kharytonoval, Olga Bielova ${ }^{2}$

\title{
LIFE AND DEATH OF NEW CITIES
}

\author{
${ }^{I}$ PhD architecture, Associate Professor, \\ Department of Architecture of buildings and structures \\ Institute of Architecture and Art, \\ e-mail: alinaharitonova@ukr.net \\ orcid: 0000-0001-6710-7089 \\ ${ }^{2}$ Odessa state academy of civil engineering and architecture, Odessa
}

Received: 22.08.2020 / Revised: 01.09.2020 / Accepted: 15.03.2021

(C) Kharytonova A., Bielova O., 2021

https://doi.org/10.23939/as2021.01.058

Astract. The article discusses the issues of architectural genesis, rapid implementation, the realities of development, life and death of new Soviet cities, as a necessary prerequisite for our attempt to understand and, possibly, resolve some of the key problems of the current trend of degradation of the urban planning environment of the Soviet period. This can give us the clearest understanding of the changes currently taking place in human nature and social order, and will allow us to more deeply analyze urban planning decisions when designing new settlements.

Key words: new town; degradation; urban planning; living environment

\section{Problem statement}

Cities rebuilt from clear sheet, in deserts or in an open field, around non-competitive territories of industrial complexes are very problematic and are currently degrading. It is a rare occurrence that such settlements can be considered sustainable in development and socially viable. The most important urban planning problem is the return of the social structure and architectural appearance of new cities. For architecture and urban planning, the time has come for research, multilateral analysis, scientific conclusions, the search for new ideas in the design of new cities. Deciding whether to build new cities, how difficult it can be; what are the main factors influencing their emergence and successful implementation, what should be the approach to the design and development of a modern city?

\section{Analysis of recent research and publications}

At the end of the XX beginning of the XXI century, scientific works appeared in Ukraine and Kazakhstan - I. Fomin, V. Yezhov, V. Timokhin, V. Vadimov, V. Didyk, A. Pavlov, T. Pavlenko, devoted to general theoretical urban planning issues, methodological foundations urbanized systems, their selforganization and harmonious direction of evolution. (Didyk V. V., Pavliv A. P., 2006. P.412) The main regulatory framework developed in the post-Soviet period is concentrated in DBN 360-92** "Mistobuduvannya. Planning and forgetting of towns and villages" (DBN 360-92**, 2000. Urban planning. Planning and construction of urban and rural settlements, P.100) and SNiP RK 3.01-01-2008. Urban planning planning and development of urban and rural settlements. However, the laws by which the cities lived earlier do not work. At the present stage, urban planning science has acquired a large arsenal of architectural tools to form the environment for activity. But this is not reflected in the legislative 
framework of the new post-Soviet countries. The creation of a living environment that would satisfy the high material and spiritual needs of a person and stimulate the development of the individual and society as a whole is the subject of intensified searches of modern sociologists, urban planners and architects.

\section{Purpose of the article}

Identification of the urban planning problem of the degradation and disappearance of new Soviet cities, identification of some of the main trends and factors of this process. Emphasis on pressing social, economic and environmental issues due to political shifts and inflexibility built by the state and architects of monotowns.

\section{Results and discussions}

The ghost cities listed here are just a drop in the ocean of cities that are simply quietly erased from the map of the planet, taking with them their history, which no one else knows about. Disappearing, the city takes with it the lives of people, the memory of the city that existed for quite a long time. Studying this topic is a necessary prerequisite for our attempt to understand and perhaps resolve some of the key problems of the current trend of dying of some cities during the Soviet period. This can give us the clearest understanding of the changes currently taking place in human nature and social order, and will allow us to more deeply analyze urban planning decisions when designing new settlements (Kharytonova A., Shuldan L., Shtendera A., 2018. p. 21-29). The abandoned cities of Kazakhstan, like the remnants of a great empire called the USSR, clearly demonstrate how vulnerable and temporarily any society, civilization, state or economic structure.

The first city in the list is Zhanatas (Dzhambul region), one of the largest abandoned cities in Kazakhstan. Its origin in 1969 is associated with the developing mining industry - the extraction of phosphorites. But with the collapse of the USSR and the closure of the phosphorite mining plant, mass departures of people began from the city. The breakdown of industrial chain ties led to the fact that the enterprise for which the city was created could not provide its employees. Today there is only a small group of people who are supplied with electricity and water for several hours a day.

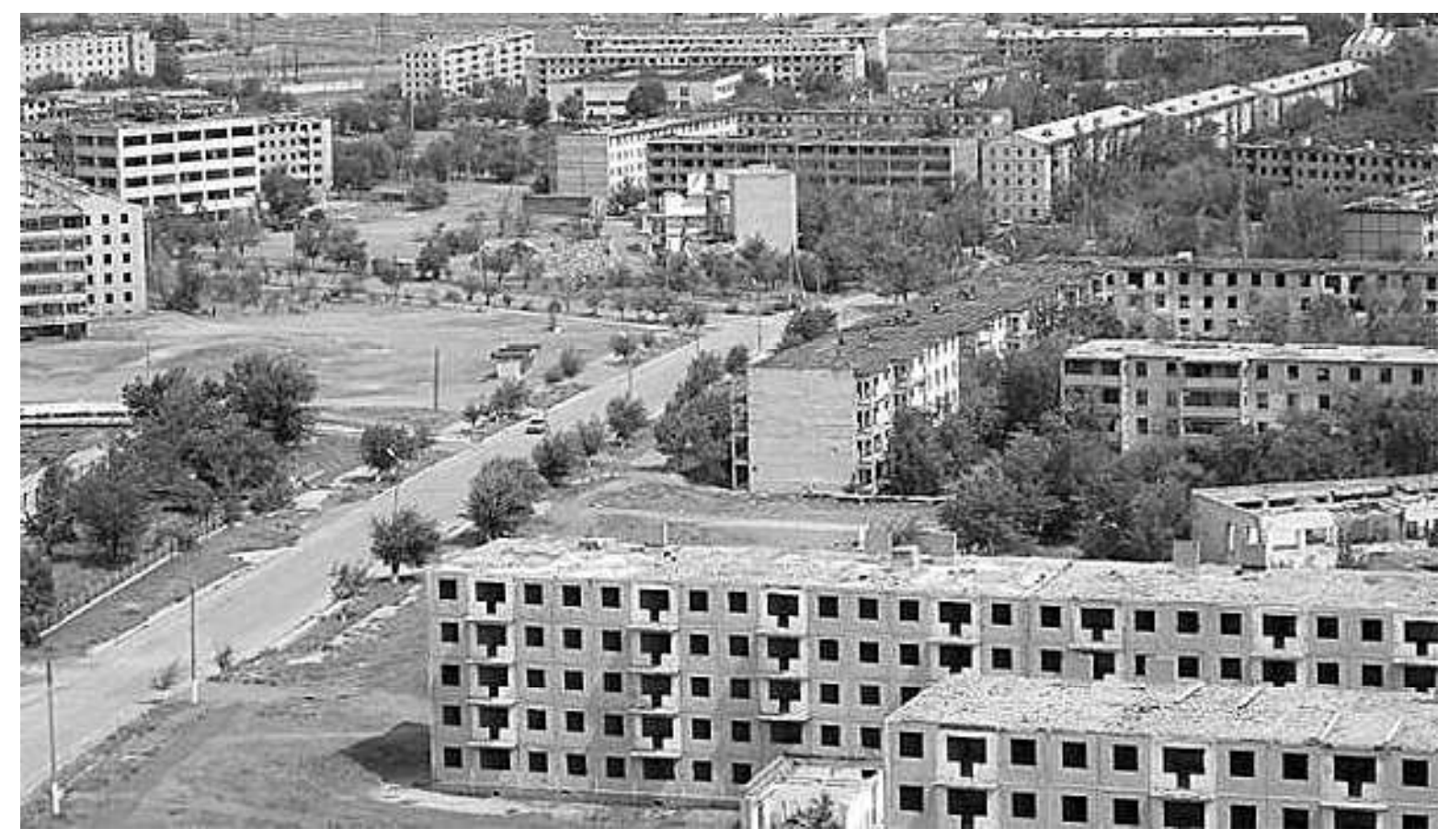

Fig. 1. The city of Zhanatas. The Republic of Kazakhstan (Kazakhstan. 2020) 
Chagan or Semipalatinsk-4 is a former closed urban-type settlement in the Semipalatinsk region, located $74 \mathrm{~km}$ away. from the city of Semipalatinsk on the banks of the Irtysh River. The city was founded in 1950, abandoned after the withdrawal of Russian troops in 1995. The main service of the residents took place at the military airfield, where long-range bombers were based. From 1958 to 1962, the most active tests took place at the test site: about eighty atomic and thermonuclear devices were detonated on the ground and in the air. Due to the fateful proximity of the city to the Semipalatinsk test site, Chagan was classified as a zone of extreme radiation risk: and after the collapse of the USSR, its residents began to receive social compensation for the harm received. In 1995, all military units were withdrawn, and the town was transferred to the Republic of Kazakhstan, after which it was quickly looted.

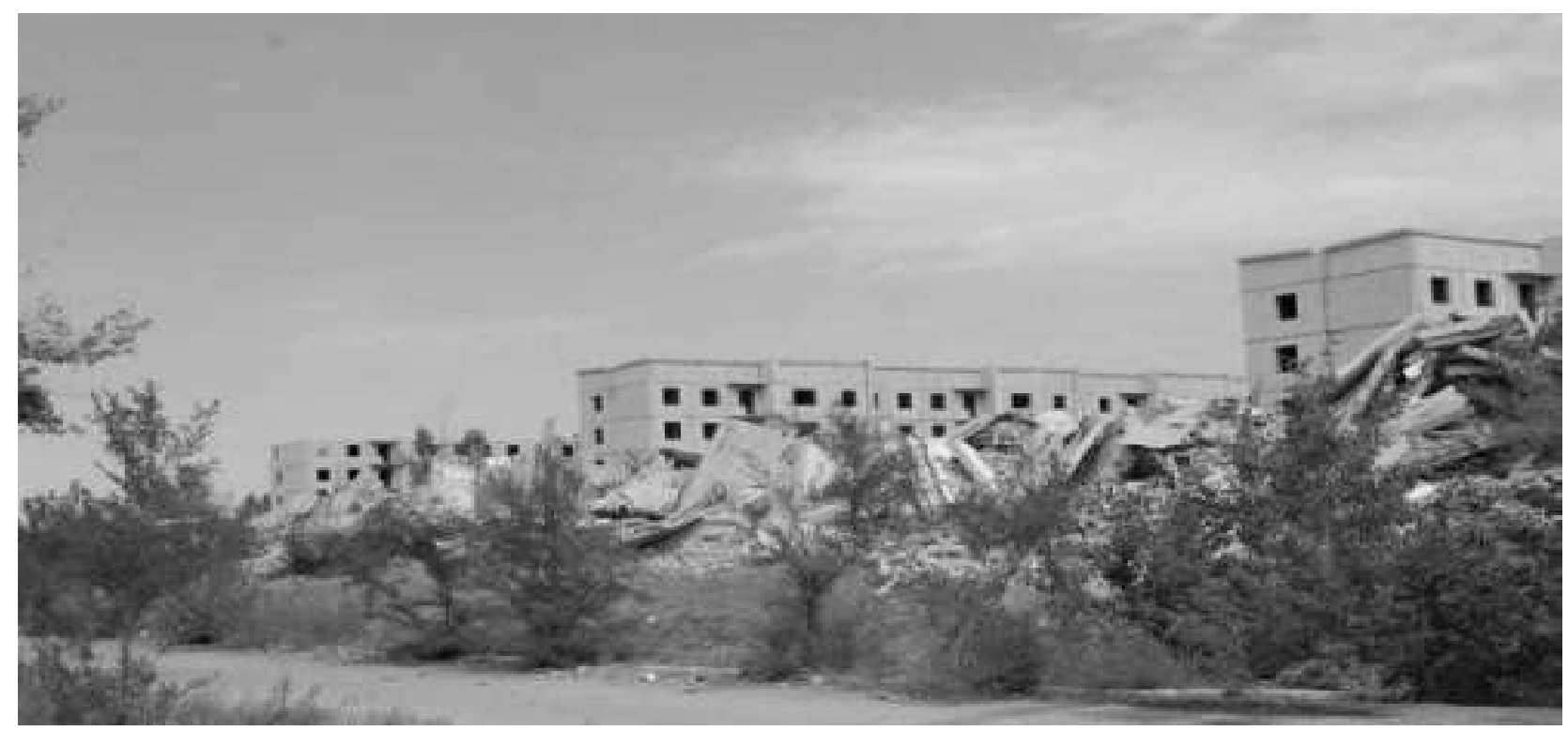

Fig. 2. City Chagan or Semipalatinsk-4

(Kazakhstan. 2020)

Priozersk. Closed city (ZATO) in the Karaganda region of Kazakhstan, the administrative center of the Sary-Shagan landfill. Located in the Betpak-Dala desert, on the Korzhyntubek peninsula of the Lake Balkhash. The city of Priozersk was founded in 1956, its population was the military and civilian personnel of the anti-missile defense (ABM) test range. The settlement is the brainchild of the arms race between the USSR and the USA. The city was actively developing interceptor missiles, and also beautiful palaces of culture, restaurants were built, 60 hotels were operating. After the collapse of the Union and the subsequent reduction of the training ground, most of the servicemen left, abandoning their inhabited apartments, and today there are only 13 thousand inhabitants in Priozersk. Of the 90 high-rise buildings, about forty remained "alive" and local residents lead excursions around their destroyed city, in which there is no industry left, small business is in decline.

Zhem or Polygon Emba of Aktobe region of Kazakhstan. It was created in 1960 for testing the latest models of military equipment and weapons, for conducting training firing. The tests of the Krug, Kub, Buk, Tor, Osa, S-300V, Tunguska air defense systems were carried out at the test site. The military town of Emba-5 emerged as an administrative and residential center of the test site. By the end of $60-\mathrm{s}$, all the necessary infrastructure was created in the city to ensure life. Several houses, several hotels, several shops, a school, a kindergarten, a bakery, a boiler room, a water intake station and a water tower, a GDO, a hospital were built. In 1999 the landfill was relocated Emba-5 ceased to exist.

Arkalyk is a classic victim of Soviet economic policy. The city was founded in 1956, located between Kostanai and Nur-Sultan (Astana), was built in just 10 years, from 1956 to 1965, in the bare steppe, near the Turgai bauxite mining administration, which mined about $20 \%$ of the bauxite ore in the 
USSR. In the 1980s, Arkalyk was going to be turned into one of the industrial centers of the region; it even had a large airport capable of receiving passenger airliners; the construction of an aircraft engine plant began. The collapse of the Soviet economy in the late 1980s canceled all these plans. After the liquidation of the Turgai region in June 1988, and the freezing of industrial development programs, the city entered a period of severe socio-economic decline, lost $35 \%$ of its population and was mothballed as a backward, depressed city with a monoprofile industry.

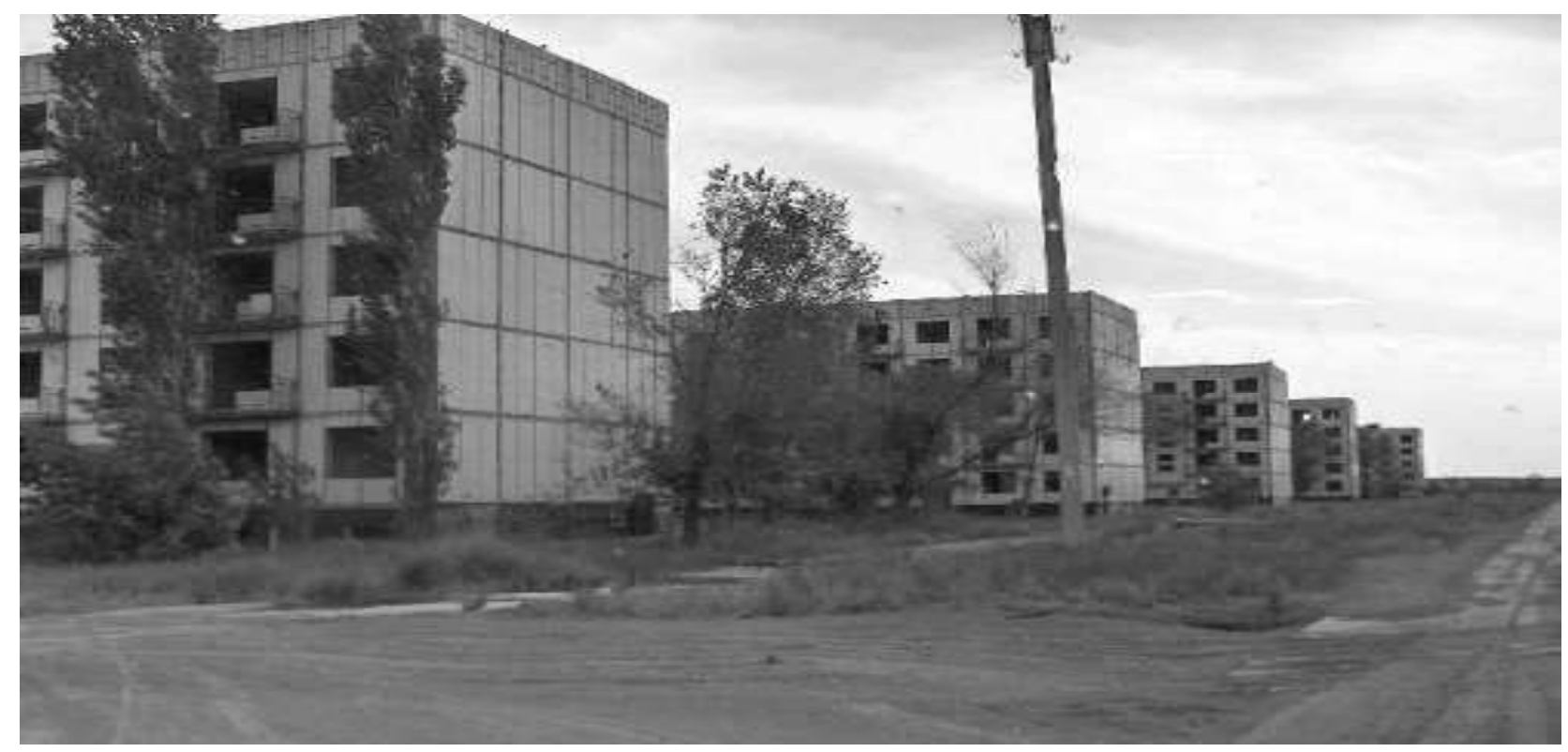

Fig. 3. City Zhem

(Kazakhstan. 2020)

At the turn of the 20th and 21 st centuries, local authorities carried out a campaign to relocate the remaining residents from the microdistricts to the compactly delineated city center, which made it possible to reduce the cost of operating communications and significantly increase the reliability of providing the population with water, heating, electricity and gas. The miracle is that even in these conditions, being virtually cut off from the rest of Kazakhstan, the city did not disappear from the map. True, now the city is on the brink of survival, but the decision to resettle Arkalyk has not been made; on the contrary, the city's survival is considered strategically important.

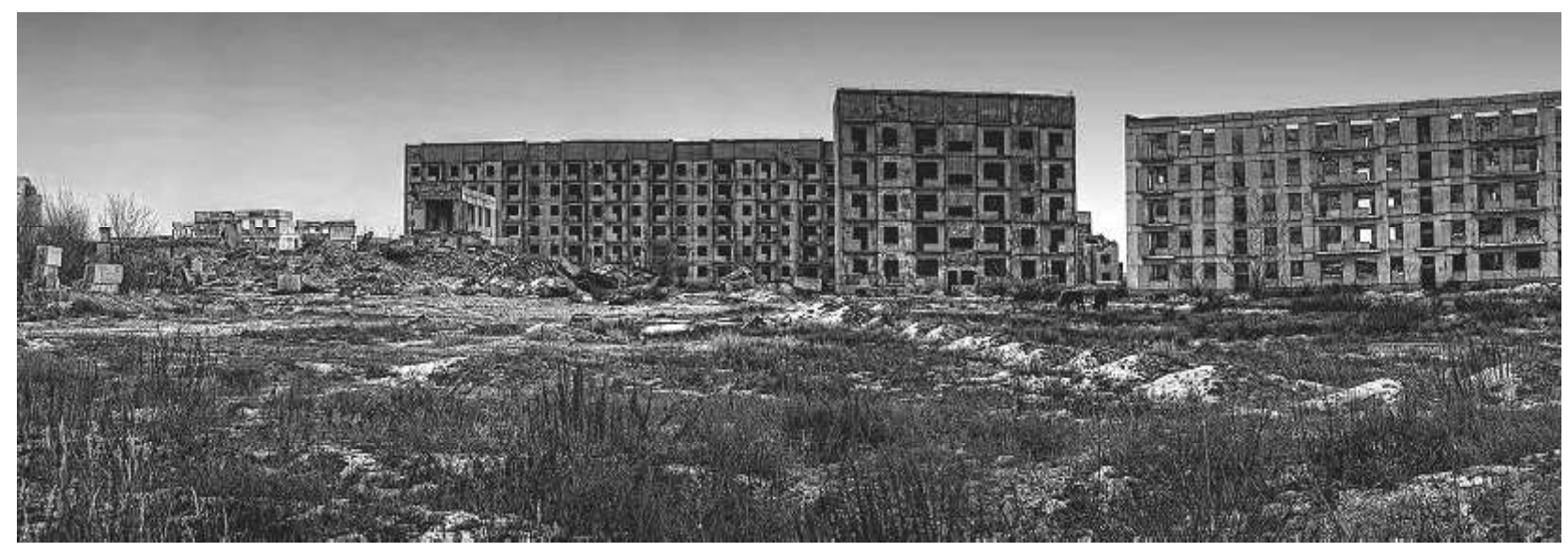

Fig. 4. City Arkalyk (Kazakhstan. 2020) 
Saran, an urban-type settlement was built for chemists, workers of a local rubber-technical plant. But when the company was declared bankrupt in 1994, most of the residents, having lost hope for the best, left their homes. Ironically, a psychiatric hospital was built here in 2010, which gives the village an even greater atmosphere of gloom and detachment.

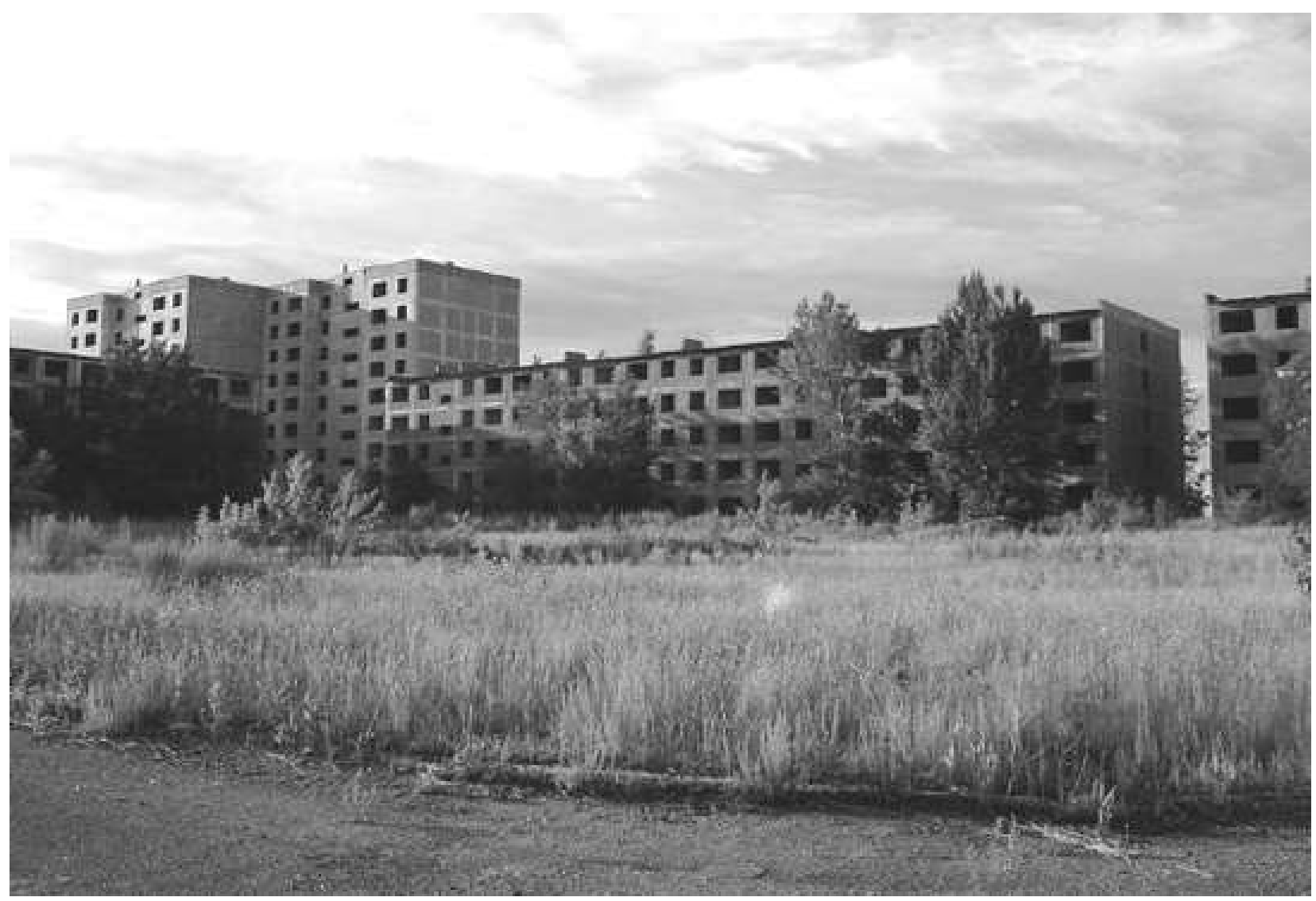

Fig. 5. Saran village (Kazakhstan. 2020)

Settlements Asubulak and Alga. In 1950-1951, a group of geologists led by Yu. A. Sadovsky discovered a group of rare-metal minerals. For the next few years, a village was built with a factory, a diesel power plant and residential buildings, schools, a hospital and all the infrastructure were built. In the 90s, the mining and processing plant was closed, the structures were dismantled for scrap, the streets were covered with garbage, and abandoned houses were looted. Today these are ghost towns.

The city of Pripyat, from which all residents (about 50 thousand people) were evacuated on April 27, 1986, is located on the banks of the Pripyat River, $3 \mathrm{~km}$ from the Chernobyl nuclear power plant, not far from the border with Belarus. The settlement was founded on February 4, 1970, and received the status of the city of Pripyat in 1979. The reason for the founding of the city was the construction and subsequent operation of one of the largest nuclear power plants in Europe, the Chernobyl plant - a city-forming enterprise. Pripyat became the ninth atomic city in the Soviet Union; 27 nationalities lived in it. The city received a peculiar face thanks to the compositions of microdistricts, which were located in radii around the city center, as well as decorative ceramics on the facades of buildings. However, the thriving city was abandoned due to the accident at the Chernobyl power plant. Now it is popular as a tourist destination. 


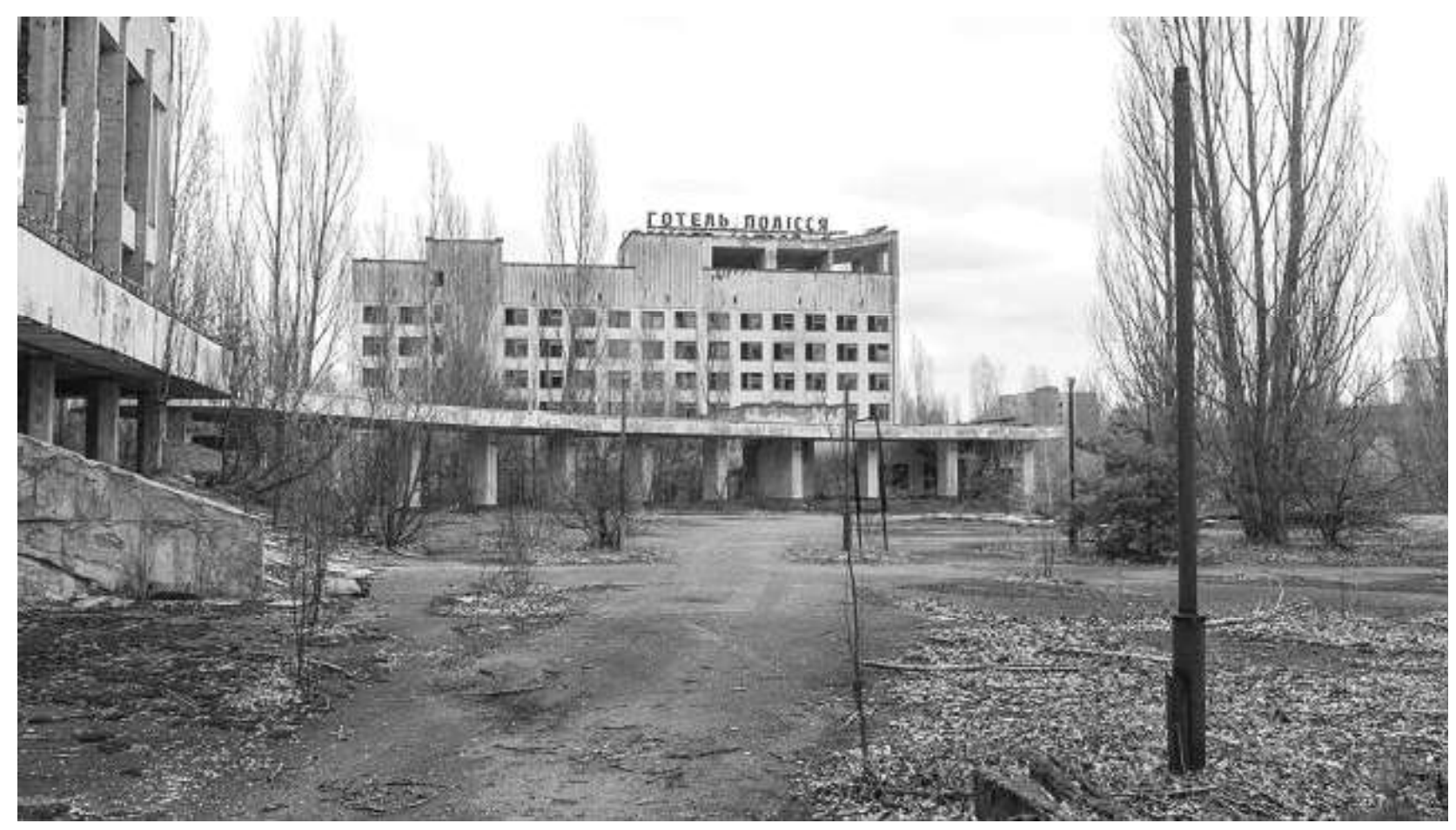

Fig. 6. The city of Pripyat. Ukraine

(Pripyat. 2020)

In many ways, the fate of these listed cities is similar to the former automobile capital of the United States - Detroit. By the beginning of the 21 st century, Detroit had become a ghost town, where most of the skyscrapers are empty, the richest theaters were destroyed, elite housing was abandoned. Several years ago, the city began to slowly recover, however, the pace is still very low. Detroit was named the most disadvantaged city in the United States. In addition to high crime rates, the environment is poor here, and in terms of unemployment, this city ranks second in the US - $10 \%$. According to Forbes, since 1950, the population has decreased by a third - to 950 thousand people, and it continues to decline due to several negative factors that overlapped. (City planning [online]. Available at: <https://lentachel.ru/news/2017/10/04/arhitektor-iz-ameriki-rasskazala-kak-planirovkagoroda-zaschitit). From the middle of the 20th century, the auto giants began to experience difficulties. In 1973, the oil crisis hit the Big Three hard, as its cars could not compete with fuelefficient European and Japanese models. This blow was followed by the energy crisis of 79, and, finally, the financial crisis of 2008-2009, which nearly finished off the American auto industry. Factories were closed one by one, and workers left the city with their families. One of the reason for the death of Detroit is the discrepancy between its "pre-automobile" urban planning structure. As a result, the city center began to die, shops and cultural establishments were closed, as customers stopped visiting them.

Another factor was the total orientation towards industrial culture - there was no cultural continuity in the city - neither a large university nor an art gallery. During the reconstruction of the city, historical buildings were not preserved, architectural monuments were demolished for the sake of offices and parking lots. One of the proposals - an artificial increase in population density with the destruction of redundant infrastructure - seems to be more than a controversial decision. The frightening views of abandoned Detroit - once the fourth largest city in the United States - have even sparked a new kind of tourism: watching a dying city. More than 370 American cities with populations exceeding 100,000 have lost over $10 \%$ of their population in the past 50 years. A quarter of emptying cities are located in the United States, mainly in the Middle East. 
Manchester. By a happy coincidence, the availability of empty city buildings began to attract students and talented youth, which contributed to the emergence of a well-known subculture. It is during the economic downturn that a special musical culture, art, architecture emerges here, which, along with a reasonable policy to support business, becomes one of the factors of urban revival. The population is shifting to the service sector, where today $70 \%$ of urban residents are employed, and unemployment is falling from $19 \%$ in 1995 to $10 \%$ in 2001. Today, 20 years after an acute crisis, Manchester is booming. According to 2010 data, the city ranks second in the UK and 12th in Europe in terms of popularity for business (What does America's newest city look like? 2020). Manchester is seen as a symbol of urban renewal, "the most thriving emptying city in the world."

\section{Conclusions}

Dying cities are an illustration of the unfulfilled hopes of people who once believed in tying their fate to this place. The distinction between space and place is fundamental to the study of urban form. This difference lies not only in the presence or absence of emotional attachment on the part of the inhabitant, but also in the peculiarities of the time. All these places were once inhabited by people who lived, loved and hoped for a bright future, but now these frightening buildings and cold empty walls are terrifying. In Europe, with the emergence and development of cities, flexible preservation and use of space arose in connection with the emergence of a corporation, an institution entitled to change over time the type of its activity (Kharytonova A., Kramarenko M., 2019. p. 83-91). Economics has given rise to a combination of a functional relationship to space and a perspective relationship to time. Cities are preserved by capturing perspectives and adapting to circumstances that can be used to their advantage.

\section{References}

DBN 360-92**, 2000. Urban planning. Planning and construction of urban and rural settlements. K. :Ministry of Regional Development of Ukraine. P. 100.

Didyk V. V., Pavliv A. P., 2006. Urban planning: pidruchny`k. Lviv : Lviv Polytechnic National University Publishing House. P. 412.

Vadimov V. M., 2003. Methodological bases of ecological and town-planning development of riparian urbanized territories (in the conditions of Ukraine): Abstract of the dissertation. : 18.00.01 / Publishing House of Kyiv National University of Construction and Architecture. Kyiv: Scientific World. P. 37.

Kharytonova A., Shuldan L., Shtendera A., 2018. "Problems of architecture and urban plenning of new cities (on the example of the city of Aktau (Shevchenko)". The Electronic Jornal-number 17, D-r 2018, Osijek, Croats Faculty of Civil Engineering, p. 21-29.

Kharytonova A., Kramarenko M., 2019. "Features of urban development at sea settlement”. Sborny`k nauchnyirh trudov "Problems of Theory and History of Architecture of Ukraine Issue 19, Odessa: Institute of Architecture and Art: ODABA. p. 83-91.

Timokhin V. A., 2004. Harmonization of the evolutionary dynamics of urban planning systems:

Abstract of the dissertation : 18.00.01 / Publishing House of Kyiv National University of Construction and Architecture. Kyiv : Scientific World. P. 34.

What does America's newest city look like? 2020 [online]. Available at: <https://uainfo.org/blognews/1529803396-kakvyglyadit-samyy-novyy-gorod-ameriki-foto.html $>$ [Accessed date: 14.09.2020].

City planning 2020 [online]. Available at: <https://lentachel.ru/news/2017/10/04/arhitektor-iz-ameriki-rasskazala-kakplanirovka-goroda-zaschitit $>$ [Accessed date: 14.09.2020].

Johnstown 2020 [online]. Available at: <https://www.bbc.com/russian/features-38000427>. Accessed date: 14.09.2020].

Kazakhstan. 2020 Abandoned cities of Kazakhstan [online]. Available at: <https://www.nur.kz/1778460-zabrosennyegoroda-kazahstana.html > [Accessed date: 14.09.2020].

Pripyat 2020 [online]. Available at: <https://funtime.kiev.ua/where-to-go/pripyat $>$ [Accessed date: 14.09.2020]. 


\author{
Харитонова Аліна', Бєлова Ольга \\ ${ }^{1}$ Канд. арх., дои. кафедри архітектури будівель та споруд \\ Архітектурно-художній інститут, \\ e-mail: alinaharitonova@ukr.net \\ orcid: 0000-0001-6710-7089 \\ ${ }^{2}$ Одеська державна академія будівництва і архітектури, Одеса
}

\title{
ЖИТТЯ І СМЕРТЬ НОВИХ МІСТ
}

Анотація. У статті розглянуті питання архітектурного генезису, стрімкого втілення, реалії розвитку, життя $i$ вмирання нових радянських міст, як необхідна попередня умова нашої спроби зрозуміти $і$, можливо, вирішити деякі ключові проблеми сучасної тенденції деградації містобудівного середовища радянського періоду. Це також важливі загальносвітові урбаністичні питання - повернення сочіальної структури і архітектурного вигляду нових міст. Закони, за якими жили міста раніше - не прачюють. На сучасному етапі містобудівна наука набула великий арсенал архітектурних засобів для формування середовищної діяльності. Створення життєвого оточення, яке задовольняло б високі матеріальні і духовні потреби людини і стимулювало розвиток особистості і суспільства в ијілому, - предмет посилених пошуків сучасних сочіологів, містобудівників і архітекторів. Але че не відображено в законодавчій базі нових пострадянських країн. Необхідна правильна постановка проблеми, яка може дати нам найчіткіше розуміння змін, щзо відбуваються в даний час у людській природі і соиіальному порядку, дозволить глибще аналізувати містобудівні рімення при проектуванні нових поселень. Вони яскраво демонструють наскільки вразливе і тимчасове будь-яке суспільство, иивілізаиія, держава або економічний уклад. Для архітектури і містобудування настав час дослідження, багатостороннього аналізу, наукових висновків, пошуку нових ідей в проектуванні нових міст. Основні питання, які треба ставити архітекторові: будувати нові міста; наскільки важким це може виявитися; які основні чинники впливають на їх виникнення і успішне здійснення; який повинен бути підхід до проектування і розвитку сучасним містом. Досвід радянського будівництва показав, щцо стійкі в розвитку і соиіально життєздатні міста, є рідкісним явищем. Економіка породила поєднання функиіонального ставлення до простору і перспективного ставлення до часу. Необхідно гнучке збереження і використання простору, яке виникло у зв'язку з появою корпорачії, міського інституту, наділеного правом змінювати з часом рід своєї діяльності. Міста зберігаються завдяки ухопленим перспективам і пристосуванню до обставин, які вдається використовувати в своїх інтересах.

Ключові слова: нове місто; деградаиія; містобудування; життєве середовище. 